\title{
Bagaimana Polisi Menangani Kasus Kekerasan Dalam Rumah Tangga (KDRT): Studi Kasus Polrestabes Semarang
}

\author{
Anggia Putri Anggraeni ${ }^{1}$ \\ Departemen Politik dan Pemerintahan, Universitas \\ Diponegoro \\ Email: anggiaputri6016@gmail.com \\ Hendra Try Ardianto ${ }^{2}$ \\ Departemen Politik dan Pemerintahan, Universitas \\ Diponegoro \\ Email: hendratrya@lecturer.undip.ac.id
}

\author{
E-ISSN (2721-0642) \\ Recieved: \\ October 112020 \\ Revised: \\ December 102020 \\ Accepted: \\ December 112020 \\ Doi Number \\ https://doi.org/10.37950/ijd.v2i3.68
}

\begin{abstract}
This article aims to understand how the police handle cases of Domestic Violence (KDRT), in particular by seeing to what extent the handling is sensitive to victims. Using the case study method, the authors conducted a qualitative analysis with research work that relied on data from the police, victims, and non-governmental organizations that provide legal assistance to victims of domestic violence. The findings in this study indicate that the handling of domestic violence cases using a restorative justice approach is much more effective than a retributive approach. The conclusion of this article shows that normatively there is a good understanding from the police to handle domestic violence issues so that they are more sensitive to victims. However, the limited number of officers, especially female officers, often appears as an obstacle to providing better victim-sensitive services.
\end{abstract}

Keywords: domestic violence (KDRT), victims of violence, police, restorative justice

\begin{abstract}
Abstrak
Artikel ini bertujuan untuk memahami bagaimana pihak kepolisian menangani kasus Kekerasan Dalam Rumah Tangga (KDRT), khususnya dengan melihat seberapa jauh penanganan tersebut memiliki sensitifitas terhadap korban. Dengan menggunakan metode studi kasus, penulis melakukan analisis kualitatif dengan kerja penelitian yang mengandalkan data dari pihak polisi, korban, dan lembaga non-pemerintah yang memberi bantuan hukum korban KDRT. Temuan dalam penelitian ini menunjukkan
\end{abstract}


bahwa penanganan kasus KDRT dengan pendekatan keadilan restoratif jauh lebih efektif dibandingkan dengan pendekatan retributif. Kesimpulan dari artikel ini memperlihatkan bahwa secara normatif sudah adanya pemahaman yang baik dari pihak polisi untuk menangani persoalan KDRT agar lebih sensitif terhadap korban. Walaupun demikian, keterbatasan jumlah petugas, khususnya dari petugas perempuan, seringkali muncul sebagai hambatan untuk memberikan layanan yang sensitif korban menjadi lebih baik.

Kata kunci: kekerasan dalam rumah tangga (KDRT), korban kekerasan, polisi, keadilan restoratif

\section{Pendahuluan}

Keberlangsungan sebuah pelayanan bersifat sebentar, tetapi dampak yang dirasakan pada masyarakat membekas lama. Hal seperti itu yang selama ini menjadi keresahan masyarakat dalam hal menggunakan jasa pelayanan khususnya pada sektor pelayanan yang berkaitan dengan hukum. Masyarakat yang menjadi korban atas suatu kejahatan seringkali tidak berani untuk speak up karena ada suatu kekhawatiran apabila pelayanan yang akan di dapat tidak pro terhadap korban. Persis di titik inilah, kasus Kekerasan Dalam Rumah Tangga (KDRT) biasanya memunculkan keengganan untuk diselesaikan melalui proses hukum di kepolisian.

Di luar itu, ada anggapan bahwa KDRT merupakan persoalan privat yang masih dalam ranah domestik. Sebab, jika terjadi perkara KDRT, baik pelaku dan korban adalah mereka yang masih memiliki hubungan tali kekeluargaan. Membawa kasus KDRT kepada polisi, seringkali dipahami sebagai mempertontonkan masalah privat ke publik. Anggapan ini tentu saja salah, bagaimanapun KDRT merupakan persoalan publik. Jika bukan masalah publik, tentu saja tidak diperlukan adanya regulasi khusus seperti UU No.23 Tahun 2004 tentang Penghapusan KDRT.

Dari sini jelas sekali KDRT adalah persoalan serius, yang coba di atur negara agar kasus semacam ini tidak terus terjadi. Sebab, penderitaan fisik dan psikis yang disebabkan KDRT dan dilakukan oleh orang terdekat, biasanya cenderung berlangsung lebih lama karena intensitas bertemu korban dan pelaku jauh lebih sering. Hal ini dapat mengakibatkan korban mengalami traumatis yang lebih parah dan lama dibandingkan apabila kekerasan itu berasal dari orang asing (Harkrisnowo, 2004). Untuk itu, penting sekali persoalan KDRT mendapat penangannya yang cepat dan tepat. Apabila tidak segera ditangani, maka kondisi kesengsaraan yang dialami korban bukan hanya menyakiti fisiknya, namun juga dapat mengganggu kejiwaannya (Dwiatmodjo, 2011).

Dikarenakan dampak yang sangat serius, maka baik individu maupun pemerintah perlu mengupayakan solusi dalam mengatasi persoalan KDRT ini. Sebagai sebuah langkah antisipasi, tiap hubungan keluarga yang terjalin harus didasari kesadaran dari masing-masing individu akan hak dan kewajibannya, agar tercipta suasana yang harmonis (Pudjiarto, 1999). Sedangkan dari sisi pemerintah, mestinya pemerintah mampu memberikan perlindungan dan pertolongan pada korban berupa rehabilitasi yang diperlukan baik secara fisik maupun psikis tanpa memandang parah atau tidaknya dampak yang di dapat oleh korban KDRT (Suahrdin, 2007).

Studi terkait fenomena KDRT bukanlah barang baru mengingat kasus seperti ini jumlahnya tergolong tinggi di Indonesia. Satu dekade yang lalu saja, menurut data yang disampaikan Kementerian Pemberdayaan Perempuan dan Perlindungan Anak RI, dari 14.399 kasus kekerasan, sebanyak 8.356 kasus terjadi di lingkungan rumah tangga 
(Purba, 2011). Tingginya kasus KDRT inilah yang kemudian memancing banyak akademisi melakukan penelitian terkait persoalan ini. Dari sekian banyak penelitian itu, penulis melihat setidaknya ada tiga kluster kecenderungan dalam melihat perkara KDRT.

Pertama adalah titik tekan pada faktor-faktor yang menyebabkan terjadinya KDRT. Kecenderungan studi dalam kluster ini biasanya berusaha untuk menemukan faktor apa saja yang biasanya menjadi penyebab lahirnya KDRT; apakah faktor ekonomi, pendidikan, ataupun kesetaraan gender (Dafeni, Mawarni, Nugroho, \& Dharmawan, 2017: Eskawati, \& Endarto, 2018). Meskipun kluster ini sering kali mengangkat kasus KDRT dengan korban perempuan, ada juga yang mengangkat kasus KDRT dengan lakilaki sebagai korban dan perempuan sebagai pelaku (Basri \& Roslan, 2018: Muljono, 2015).

Kedua, ada kecenderungan untuk mengamati bagaimana berbagai upaya pencegahan agar kasus KDRT tidak terjadi atau terulang. Beberapa upaya itu diantaranya; membentuk kader di masyarakat untuk menangani dan mendampingi korban KDRT (Soetoprawiro, Abdurrachman, Idayanti, \& Permanasari, 2013); sosialisasi pencegahan KDRT yang dilakukan oleh pemerintah khususnya dari Pusat Pelayanan Terpadu Pemberdayaan Perempuan dan Anak (P2TP2A) (Rinawati, 2017; Rafikah 2017; Bakar, 2017), dan melibatkan lembaga sosial dan keagamaan untuk mencegah terjadinya KDRT (Amilia, Mansur, \& Saifuddin, 2016).

Sedangkan kluster ketiga, adalah berfokus pada upaya penyelesaian. Dalam kluster ini, posisi peneliti terbelah dalam dua sisi. Satu sisi, mereka yang melihat upaya penyelesaian dari jalur formal, seperti melalui polisi atau pengadilan (Arief, \& Rahmah, 2018; Tedjosaputro \& Krismiyarsi, 2012; Ludfi, Jumiati, \& Hidayati, 2018). Sedangkan sisi lainnya memfokuskan cara penyelesaian melalui jalur informal, misalkan melalui lembaga sosial atau memakai kaidah norma-norma sosial sehari-hari (Lumbanbatu, \& Hidir, 2019).

Di titik inilah penulis ingin mengisi diskusi persis di kluster bagaimana polisi berperan dalam penanganan persoalan KDRT, khususnya yang terjadi di kantor Polrestabes Semarang. Penelitian seperti itu meskipun bukan baru, tetapi masih jarang dilakukan. Jikapun ada artikel-artikel yang mengangkat peran polisi, kecenderungan umumnya seringkali menggunakan pendekatan formal-yuridis (Simbolon, 2020). Kecenderungan lainnya juga biasanya hanya menangkap peran polisi dalam kerja penyuluhan dan sosialisasi penghapusan KDRT (Hidayati, 2016: Sudarty, Nur, Nawawi, Arfa, \& Erwin, 2019).

\section{Kerangka Teori}

Secara umum, polisi memiliki dua peran pokok, yakni sebagai agen penegakan hukum (law enforcement agency) dan sebagai agen yang memelihara keamanan dan ketertiban masyarakat (order maintenance officer). Dalam mengupayakan dua peran itu, polisi menjalankan dua fungsi sekaligus, yakni fungsi pencegahan (preventif) dan fungsi penindakan (represif) sebagai bagian dari dibentuknya agen kepolisian (Aaron, 1991). Pada titik ini, maka bisa dilihat bahwa polisi merupakan garda depan dalam tegaknya tertib hukum di suatu negara. Hal ini sejalan dengan landasan bahwa undang-undang merupakan sumber hukum yang utama, maka eksistensinya sangat menentukan keadaan tertib hukum itu sendiri (Mansur, Arief, \& Gultom, 2007).

Adanya peraturan perundang-undangan bukan serta-merta otomatis menjadi tertib hukum. Sama halnya dengan adanya UU No.23 Tahun 2004 tentang Penghapusan KDRT, tidak lantas kasus KDRT kemudian menghilang. Bahkan, meskipun sudah ada 
UU tersebut, korban KDRT adakalanya tidak langsung mau melaporkan tindak kekerasan yang mereka alami. Ada banyak hambatan dan alasan mengapa mereka seperti itu, misalkan merasa malu karena merasa hal tersebut merupakan ranah privasi yang akan menjadi aib apabila diketahui oleh orang lain. Selain itu, ada juga rasa tidak berdaya dan selalu ingin bergantung kepada suami serta rasa khawatir akan tanggapan aparat kepolisian dalam penanganan kasus adalah alasan para korban masih enggan buka suara atas tindak kekerasan yang mereka alami (Sulistyowati, 2006).

Kondisi di atas jika terus dibiarkan akan melahirkan rasa tidak percaya dari masyarakat kepada pihak kepolisian untuk menjadi tempat pertama bagi mereka meminta perlindungan atas kekerasan yang mereka alami (Raharjo, 2009). Untuk itu diperlukan sebuah kinerja kepolisian yang benar-benar mampu memberikan layanan sebagaimana yang menjadi ekspektasi masyarakat. Guna menghasilkan pelayanan yang sesuai dengan espektasi tersebut, maka pihak kepolisian wajib untuk menjalankan pelayanan prima.

Pelayanan prima ini merujuk pada Keputusan Menteri Pedayagunaan Aparatur Negara Nomor 63/KEP/M.PAN/7/2003 tentang Pedoman Umum Penyelenggaraan Pelayanan Publik. Diluar itu, layanan yang diberikan kepolisian juga mengacu pada Peraturan Kapolri Nomor 3 Tahun 2008 mengatur tentang Pembentukan Ruang Pelayanan Khusus dan Tata Cara Pemeriksaan Saksi dan/atau Korban Tindak Pidana. Dengan manyandarkan pada dua ketentuan itu, maka pihak kepolisian bisa memberikan pelayan prima, dalam pengertian "sebagai output yang diberikan oleh penyedia jasa untuk dapat melayani pengguna jasa secara maksimal" (Barata, 2003).

\section{Metode Penelitian}

Dalam melakukan penulisan artikel ini, penulis menyandarkan pada penelitian kualitatif dengan metode studi kasus. Penelitian studi kasus merupakan model penelitian yang menjelaskan secara detail suatu kasus spesifik, namun tetap memberikan batasan pada lingkup kasus yang diteliti (Creswell, 2016). Artinya, titik perhatian kasus ada pada kasus KDRT, sedangkan batasannya ada pada kasus yang dilaporkan di Polrestabes Semarang saja. Batasan ini penting karena bisa jadi jumlah perkara KDRT sebenarnya jauh lebih besar dari jumlah kasus yang masuk di Polrestabes Semarang.

Saat penelitian, penulis mengandalkan data-data dari informan yang sudah ditentukan secara purposive. Data dikumpulkan dengan teknik wawancara mendalam, ditambah juga melakukan observasi harian dengan cara salah satu penulis terlibat magang di Polrestabes Semarang selama kurang lebih satu bulan. Selanjutnya, data-data yang terkumpul kemudian dikategorisasikan sesuai dengan lingkup yang akan ditulis.

Pengatagorian ini dilakukan untuk mereduksi data yang sekiranya tidak diperlukan. Selanjutnya data yang telah direduksi, kemudian dinarasikan dengan cara menjelaskan secara terperinci atas pendapat atau pemikiran yang telah diungkapkan informan kemudian disimpulkan menjadi sebuah narasi. Karena penelitian penelitian ini memakai desain studi kasus, maka kesimpulan yang diambil merupakan kesimpulan yang bersifat umum. Namun agar tidak begitu meluas, peneliti tetap membatasinya pada lingkup studi kasus yang telah ditentukan.

\section{Hasil dan Diskusi \\ Bagaimana Korban KDRT Mendapat Perlindungan}

Secara umum, kekerasan biasanya dipahami sebagai tindakan pemukulan, penganiayaan, pemerasan, dan pemerkosaan, baik secara fisik maupun psikis. KDRT 
dapat dilakukan oleh siapapun dalam keluarga, baik itu suami, istri, maupun anak, yang kemudian memiliki dampak buruk pada keharmonisan keluarga bahkan luka fisik maupun trauma psikis yang serius. Persoalan KDRT ini semakin kompleks ketika tingkat kesadaran hukum di masyarakat masih rendah. Akibatnya, banyak dari mereka yang mengalami KDRT lebih memilih melakukan perceraian dari pada mengandalkan proses hukum untuk mengakhiri perkara KDRT. Apalagi, ada kesan di masyarakat bahwa proses penyelesaian perkara seperti ini akan berlarut-larut dan memakan biaya yang banyak.

Melihat situasi di atas, maka dibutuhkan peran aparat hukum yang jauh lebih baik. Aparat hukum dituntut untuk mampu mencegah dan menanggulangi tindak pidana KDRT. Kasus KDRT sebenarnya tidak terjadi hanya pada kalangan menengah ke bawah saja, tetapi juga seringkali menimpa masyarakat dengan strata ekonomi atas. Kelas ekonomi manapun bisa menjadi pelaku maupun korban dalam kasus KDRT, bahkan aparat penegak hukum sekalipun. Demi memperjuangkan penyelesaian masalah ini, Undang-Undang Penghapusan KDRT terus disosialisasikan secara bersama-sama oleh pemerintah maupun NGO. Sosialisasi ini penting agar muncul kesadaran masyarakat terkait persoalan KDRT, dan diharapkan jumlah KDRT bisa menurun.

Bagaimana pun juga, kasus KDRT di Kota Semarang cukup tinggi. Menurut data yang disampaikan oleh PPT SERUNI Kota Semarang menunjukkan bahwa ada 281 aduan kasus KDRT pada 2015. Jumlah itu kemudian naik di tahun 2016 menjadi 271 aduan. Setahun berikutnya terjadi peningkatan lagi menjadi 305 aduan pada 2017. Ada dua kemungkinan mengapa jumlah ini naik, pertama bisa jadi karena tindak kekerasan yang memang naik dari tahun ke tahun, atau kemungkinan kedua karena sudah muncul kesadaran dan keberanian korban melaporkan tindak kekerasan yang menimpa dirinya (Budi, 2016). Sedangkan untuk data yang masuk di Polrestabes Kota Semarang, bisa dilihat di tabel 1.

Tabel 1 Jenis Kasus KDRT yang Masuk di Polrestabes Semarang

\begin{tabular}{|l|l|l|}
\hline Tahun & Jenis Kekerasan & Jumlah \\
\hline \multirow{4}{*}{2014} & Fisik & 47 \\
\cline { 2 - 3 } & Psikis & 1 \\
\cline { 2 - 3 } & Penelantaran & 6 \\
\hline \multirow{3}{*}{2015} & Fisik & 38 \\
\cline { 2 - 3 } & Psikis & 0 \\
\cline { 2 - 3 } & Penelantaran & 1 \\
\hline \multirow{3}{*}{2017} & Fisik & 26 \\
\cline { 2 - 3 } & Psikis & 0 \\
\cline { 2 - 3 } & Penelantaran & 2 \\
\hline \multirow{3}{*}{2018} & Fisik & 8 \\
\cline { 2 - 3 } & Psikis & 0 \\
\cline { 2 - 3 } & Penelantaran & 0 \\
\hline & Fisik & 3 \\
\cline { 2 - 3 } & Psikis & 0 \\
\cline { 2 - 3 } & Penelantaran & 0 \\
\hline
\end{tabular}

Bagaimana korban KDRT ditangani oleh kepolisian, maka kaidah normatifnya adalah sebagai berikut. Mulanya, korban KDRT diberikan pemahaman tentang hak 
mereka, diantaranya dalam waktu $1 \times 24$ jam terhitung sejak mengetahui atau menerima laporan KDRT, kepolisian akan segera memberikan perlindungan sementara pada korban. Polisi juga bisa berkolaborasi dengan stakeholder lain untuk membantu proses perlindungan korban, seperti tenaga kesehatan, pekerja sosial, relawan minimal selama 7 hari. Adapun alur urutan pelaporan kasus KDRT bisa dilihat pada Bagan 1.

\section{Bagan 1: Alur Pelaporan Kasus KDRT}

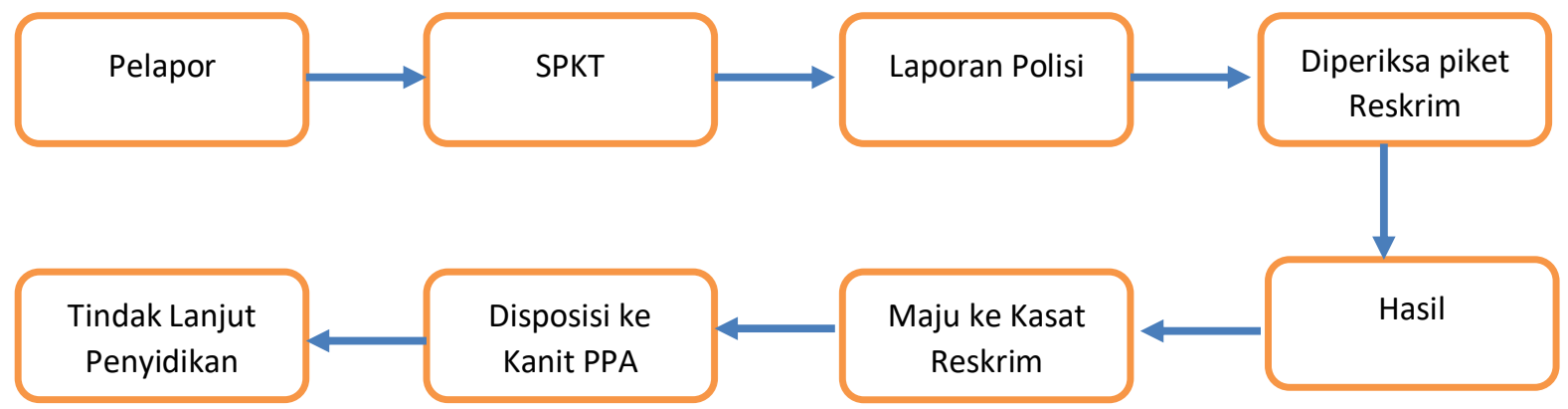

Setelah adanya laporan masuk, pihak kepolisian diwajibkan untuk segera memproses kasus tersebut dengan langsung melakukan penyelidikan dan apabila bukti dan saksi sudah terpenuhi maka dilanjutkan ke proses penyidikan. Apabila terbukti bersalah, maka penyidik berhak melanjutkan langkah dengan melakukan penangkapan serta penahanan terhadap pelaku KDRT sebagai wujud perlindungan pada korban. Meskipun dalam undang- undang telah diatur adanya perintah untuk melakukan perlindungan sementara pada korban kekerasan dalam rumah tangga tetapi dalam realitanya tidak semua kasus KDRT si korban mendapatkan perlindungan sementara dari kepolisian. Hal ini sebagaimana diungkapkan oleh IPDA Prastiwi Hermawati S.H menyatakan bahwa :

“Dari data laporan yang masuk mengenai kasus KDRT di Kantor Polrestabes Semarang,semua pelakunya adalah laki-laki. Perlindungan sementara juga tidak diberikan kepada seluruh korban kekerasan dalam rumah tangga, hal ini dikarenakan pihak kepolisian melihat dari tingkat bobot kasus dari masing- masing korban berbeda. Beberapa kasus yang sifatnya darurat dimana korban sudah tidak berdaya lagi atau sudah dalam keadaan darurat maka dari pihak kepolisian akan segera memberikan perlindungan sementara, namun dalam hal ini tentunya dengan persetujuan sang korban, karena ada juga korban yang menolak diberikan perlindungan sementara oleh pihak kepolisian."

Mengikuti keterangan di atas, terlihat bahwa tidak semua korban diberikan perlindungan sementara, dikarenakan jumlah personil dari kepolisian yang terbatas sehingga tidak mampu memberikan perlindungan sementara kepada seluruh korban. Meskipun demikian, setiap kasus yang dilaporkan dan tercatat dalam data Polrestabes Semarang semuanya akan dipertimbangkan apakah harus ditindaklanjuti dengan perlindungan sementara atau tidak. Ketika ada laporan yang masuk, maka polisi segera menjamin keamanannya dengan memberikan jaminan perlindungan sesuai dengan undang-undang yang berlaku kepada korban KDRT, selanjutnya menginformasikan pada korban tentang apa-apa saja hak yang seharusnya mereka dapatkan selama berjalannya proses penanganan kasus.

Setiap korban KDRT tentu saja memiliki hak untuk perlindungan oleh pihak kepolisian. Namun untuk memutuskan bentuk perlindungan sementara seperti apa yang diberikan oleh kepolisian, pihak kepolisian harus melihat bobot berat atau ringannya 
kasus yang di hadapi korban tersebut. Dalam proses penyelidikan, polisi memberi kesempatan kepada korban untuk dapat menjelaskan kejadian yang terjadi kepadanya agar polisi dapat keterangan yang lebih jelas untuk nantinya dapat diputuskan apakah dapat di lanjut ke proses penyidikan atau tidak. Dengan melalui proses ini maka polisi akan mendapatkan bukti yang lebih kuat dan segera menempatkan korban ke tempat yang lebih aman.

Meskipun terlihat bahwa proses perlindungan sepertinya sudah berjalan secara profesional dan proporsional, namun penulis menemukan fakta yang berbeda sebagaimana dicatat oleh Glorianto (2011) sebagai berikut:

"Pada kasus SD, Penulis (Glorianto-pen.) menemukan bahwa pihak Kepolisian belum menjalankan kewajibannya untuk memberikan perlindungan sementara seperti yang diharapkan. Korban yang datang sendiri ke kantor polisi dengan kakak kandungnya hanya dilayani untuk melakukan pencatatan BAP, dan diperbolehkan untuk kembali kerumahnya, tanpa adanya perlindungan sementara dari polisi.

Dari fakta ini, sebenarnya terlihat bahwa kepolisian kurang memiliki kecekatan dan kecepatan dalam merespon kebutuhan korban.

Untuk tindak kekerasan yang berbentuk fisik, kepolisian tentu lebih cepat tanggap dalam memutuskan perlu tidaknya perlindungan sementara pada korban. Sebaliknya, untuk jenis kekerasan yang bersifat psikis, seringkali penyidik mengalami kesulitan untuk memutuskan bentuk pelindungannya, dan lebih sulit lagi ketika ingin memutuskan upaya penahanan pada pelaku. Hal itu terjadi karena bukti tekanan psikis pada korban membutuhkan justifikasi yang tidak mudah. Hal inilah yang sering menimbulkan keraguan bagi pihak kepolisian dalam memproses kasusnya, karena tingkat kegawatan pada korban juga akan mempengaruhi jenis hukuman yang akan dijatuhkan pada pelaku. Untuk itu, dalam konteks seperti ini diperlukan adanya justifikasi dari dokter ataupun psikiater demi melakukan penyelidikan yang lebih mendalam terhadap korban hingga nantinya dapat mengadili pelaku secara adil dan profesional.

Bagaimana pun juga, kasus KDRT merupakan kasus yang sulit untuk diselesaikan, bahkan ketika selesai pun, belum tentu korban bisa dengan tenang keluar dari kesulitan traumatisnya. Hal ini sejalan dengan pendapat PPT SERUNI, bahwa perkara KDRT membutuhkan waktu yang cukup lama untuk korban menyelesaikan masalahnya. Untuk itu, korban KDRT membutuhkan pendampingan yang ekstra, karena masalah ini bersangkutan dengan keluarga inti, menyangkut tentang anak dan ekonomi keluarga. Oleh karena itu, wajar jika korban tidak mau menceritakan masalah tersebut ke semua orang. Dalam mengatasi masalah ini, menurut PPT SERUNI pendekatan secara sosial, seperti membuat seminar bagi perempuan, dan sosialisasi tentang UU Penghapusan KDRT.

Kasus KDRT di Semarang ini memang perlu mendapat perhatian serius, mengingat tingginya kasus yang muncul. Pada tahun 2016 LBH APIK Semarang telah menangani 64 kasus, dengan rincian terdapat 37 kasus perdata dan 16 kasus pidana, dan 11 kasus sekaligus pidana dan perdata. Kasus berdasarkan jenis kekerasan, sebagian besar kasus yang ditangani oleh LBH APIK Semarang adalah kasus KDRT sebanyak 43 kasus. Data kasus berdasarkan jenis KDRT, dapat dilihat bahwa setiap kekerasan yang dialami oleh korban akan berdampak pada kondisi psikis korban, sehingga pemulihan psikis korban menjadi penanganan yang penting selain penanganan hukum. Pada tahun 2017 data dari LBH APIK Semarang menunjukkan danya sedikit penurunan, yakni sebanyak 30 kasus. 
Jenis KDRT tertinggi adalah KDRT fisik, psikis dan penelantaran ekonomi (Hardiyanti, Purwanti, \& Wijaningsih, 2018).

Selama ini, kepolisian memang selalu berkolaborasi dengan pihak lain, terutama lembaga layanan rujukan bagi penanganan korban kekerasan terhadap perempuan dan anak yang ada di Kota Semarang. Beberapa diantara lembaga rujukan ini diantaranya adalah PPT SERUNI Kota Semarang dan LBH APIK Semarang. Keduanya memiliki fungsi pemberian bantuan perlindungan hukum bagi korban kekerasan perempuan dan anak khususnya yang berada di Kota Semarang.

Bantuan hukum berfungsi sebagai media bagi semua orang agar bisa menuntut haknya seandainya diperlakukan tidak sesuai dengan hukum normatif yang berlaku. Untuk itu, penting menempatkan siapa saja sebagai subjek hukum agar proses penegakan hukum bisa terus ditegakkan. Sayangnya, ada kalanya masyatakay tidak mampu secara finansial untuk menuntut haknya sesuai dengan tata prosedur yang berlaku. Oleh sebab itu, dibutuhkan adanya suatu mekanisme lain yang bisa diakses masyarakat secara featis, inilah yang dikenal dengan berperkara secara prodeo, yakni melalui lembaga-lembaga bantuan hukum yang telah ada.

\section{Bagaimana Polisi Menyelesaikan Kasus KDRT}

Setelah proses penyelidikan dilakukan, maka pihak kepolisian akan menghasilkan berita acara sambil melakukan proses mediasi antara pihak pelaku dan pihak korban, dimana masing-masing didampingi oleh kuasa hukum. Proses mediasi dalam hal ini tentunya dilakukan di depan penyidik dan kejaksaan untuk nantinya dapat menemukan titik terang atas permasalahan tersebut. Proses penanganan kasus KDRT yang dilakukan melalui hukum pidana tetap membutuhkan kesadaran para aparat kepolisian, khususnya terkait police women desk sebagai bukti kepekaan aparat kepolisian terhadap korban KDRT yang diwujudkan dengan adanya ruang pelayanan khusus (RPK).

Tidak sembarang aparat bisa ditugaskan dalam RPK. Mereka yang tergabung sebagai Tim Penyidik dan bertugas di RPK harus menjalani pelatihan khusus dalam penanganan kasus KDRT di Mabes Polri terlebih dahulu. Dalam menjalankan tugasnya, penyidik yang bertugas di RPK tentunya harus memiliki sikap ramah, sopan, dan juga ikhlas dalam membantu menyelesaikan kasus terkait KDRT. Selain itu, aparat di dalam RPK juga harus memiliki daya kreativitas, mampu menciptakan komunikasi yang baik sehingga pelapor dapat dengan nyaman menjalani setiap proses yang ada.

Proses yang dilakukan setelah penyidikan dan pelaku dinyatakan bersalah adalah yang pertama dengan memberikan perlindungan pada korban hingga dirasa sudah pulih atau paling lama satu tahun. Setelah itu penyidik bersama tersangka bersama-sama menyerahkan berkas perkara di kejaksaan untuk selanjutnya dapat menjalankan proses pemeriksaan di pengadilan dengan diawali pembacaan hasil mediasi oleh penyidik, baru dilakukan pemerikasaa saksi dan barang bukti yang dalam hal ini termasuk hasil visum. Jika saksi dan bukti sudah dirasa cukup, maka akan dilakukan pembacaan tuntutan hukuman atas tersangka yang kemudian dilanjutkan dengan proses pembacaan pleidoi dari kemudian berakhir dengan putusan hakim.

Dalam upaya penanganan kasus KDRT, pihak kepolisian menggunakan pendekatan keadilan restoratif, yakni memperbaiki hubungan yang adil antara pihak pelaku dan korban atas dasar kesepakatan kedua pihak, dalam hal ini mendorong pelaku untuk dapat berubah dan menyadari atas kesalahan yang telah diperbuatnya. Untuk mencapai keadilan restoratif ini, tentu saja dibutuhkan peran aktif, baik dari korban maupun masyarakat untuk dapat menemukan titik temu atas permasalahan terkait 
kasus KDRT. Tujuan dilakukannya keadilan restoratif adalah usaha agar keutuhan rumahtangga sebisa mungkin dapat diselamatkan.

Polrestabes Semarang telah menerapkan pendekatan restoratif, dengan lebih menitikberatkan agar korban dapat membuka suara atas kerugian yang dialaminya, dan menimbulkan rasa tanggungjawab dari pelaku untuk dapat menebus perbuatannya sesuai dengan hukum yang berlaku. Pendekatan restoratif tentunya berbeda dengan prinsip retributif yang hanya berfokus pada kesalahan pelaku tanpa melibatkan korban proses penanganannya. Sedangkan prinsip keadilan restoratif menekankan keterlibatan semua pihak agar bisa mendapatkan hasil yang disepakati secara adil dan berimbang.

Proses penanganan kasus dengan pendekatan restoratif ini sebagaimana disampaikan oleh IPDA Prastiwi Hermawati S.H. menyatakan bahwa:

"Semua laporan yang masuk tidak langsung kami proses ke peradilan, kami selalu mengusahakan dengan cara mediasi terlebih dahulu dikarenakan hubungan antara pelaku dan korban adalah hubungan keluarga. Dalam hal ini, korban dan pelaku dipertemukan dan ditawari dengan penyelesaian secara damai sehingga tidak perlu di proses secara peradilan. Namun untuk penyelesaian secara damai ini tidak semua korban dan pelaku sepakat, biasanya yang berhasil sepakat itu yang perkaranya tergolong ringan. Agar proses mediasi berjalan lancar dan tujuan dari mediasi dapat tercapai, maka peran dari mediator sangat besar. Mediator diharuskan bersikap netral dan tidak memihak. Untuk di Polrestabes sendiri tahap pendekatan restoratif itu ada tiga, dimulai dari pra mediasi, kemudian mediasi, dan yang terakhir pasca mediasi".

Bukti bahwa pendekatan restoratif ini efektif digunakan, bisa terbaca dari kasus yang diselesaikan dengan cara mediasi. Hampir sebagian besar kasus KDRT yang masuk Polrestabes Semarang, proses penyelesaian bisa berakhir dengan cara mediasi. Hal ini dilihat secara seksama pada tabel 2.

Tabel 2 Data Penyelesaian Kasus Laporan KDRT Di Polrestabes Semarang

\begin{tabular}{|c|l|c|c|}
\hline \multirow{2}{*}{ Tahun } & \multicolumn{1}{|c|}{ Jenis Kekerasan } & $\begin{array}{c}\text { Selesai di } \\
\text { Pengadilan }\end{array}$ & $\begin{array}{c}\text { Selesai dengan } \\
\text { Mediasi }\end{array}$ \\
\hline \multirow{3}{*}{2014} & Fisik & 1 kasus & 28 kasus \\
\cline { 2 - 4 } & Psikis & 0 kasus & 0 kasus \\
\cline { 2 - 4 } & Penelantaran & 0 kasus & 0 kasus \\
\hline \multirow{3}{*}{2015} & Fisik & 1 kasus & 19 kasus \\
\cline { 2 - 4 } & Psikis & 0 kasus & 0 kasus \\
\cline { 2 - 4 } & Penelantaran & 0 kasus & 0 kasus \\
\hline \multirow{3}{*}{2016} & Fisik & 0 kasus & 8 kasus \\
\cline { 2 - 4 } & Psikis & 0 kasus & 0 kasus \\
\cline { 2 - 4 } & Penelantaran & 1 kasus & 0 kasus \\
\hline \multirow{3}{*}{2017} & Fisik & 0 kasus & 8 kasus \\
\cline { 2 - 4 } & Psikis & 0 kasus & 0 kasus \\
\cline { 2 - 4 } & Penelantaran & 0 kasus & 0 kasus \\
\hline \multirow{2}{*}{2018} & Fisik & 1 kasus & 1 kasus \\
\cline { 2 - 4 } & Psikis & 0 kasus & 0 kasus \\
\cline { 2 - 4 } & Penelantaran & 0 kasus & 0 kasus \\
\hline
\end{tabular}

Sebagaimana ditunjukkan pada Tabel 2 bahwa pendekatan restoratif lebih efektif dalam menyelesaikan perkara. Dalam konteks seperti ini, maka kita bisa melihat bahwa tidak setiap perkara harus dipaksakan menggunakan mekanisme hukum, dengan hitam 
putih yang tegas. Hal ini sebagaimana dikuatkan oleh salah satu informan, IPDA Edy Purwanto selaku Kasubnit Reskrim di Polrestabes Semarang yang menyatakan bahwa: "Keadilan retributif dan restoratif sendiri memiliki penerapan masing-masing sesuai porsi dari kasus tersebut dan juga kesepakatan atas keduanya. Penerapan restoratif lebih kepada menghargai cara pandang orang yang berbeda-beda dalam menyelesaikan masalah, tidak bisa memaksakan setiap orang untuk sellau menyelesaikan suatu permasalahan dengan hukum. Apabila dilihat lagi, hukum itu punya asas dapat memberi manfaat keadilan, jadi apabila dari pihak korban telah bersedia menerima dan memaafkan pelaku maka tidak bisa dipaksakan bahwa kasus tersebut harus di bawa ke ranah hukum, karna apabila jika sudah terjadi kesepakatan diantara keduanya maka dianggap selesai"

Dari pernyataan di atas, bisa dilihat bahwa aparat lebih mengusahakan jalan damai daripada penyelesaian lewat ranah hukum. Kenyataan ini bisa dilihat dari kecenderungan polisi untuk pengupayakan perdamaian antara korban dan pelaku. Ketika korban dan pelaku sudah saling memaafkan satu dengan lainnya, maka perkara KDRT akan dianggap selesai dengan baik tanoa perlu dilanjutkan ke meja persidangan. Upaya penyelesaian seperti itu tentu saja baik, tetapi tidak semua kasus bisa diselesaikan dengan cara mediasi semacam itu karena ada beberapa hambatan.

Polisi biasanya memiliki hambatan internal, khususnya yang dihadapi oleh unit PPA. Hambatan utama yang paling sering muncul adalah persoalan sumber daya manusia dan infrastruktur yang terbatas, padahal jumlah perkara KDRT terus meningkat dari tahun ke tahun. Menurut penulis, minimnya jumlah anggota kepolisian di unit PPA ini adalah masalah serius yang terjadi hampir diseluruh resort kepolisian dimana pun. Belum lagi, dari petugas yang ada, jumlah petugas perempuan juga masih sangat minim. Hal ini persis sebagaimana data Purba (2011) bahwa hanya 4\% dari petugas penyidik adalah perempuan, jumlah tersebut tidak cukup untuk membantu perempuan korban perkosaan dan KDRT dan untuk menangani tersangka kriminal perempuan. Beberapa persoalan ini yang menjadi akar masalah dimana layanan penanganan atas kasus KDRT tidak berjalan maksimal. Seandainya personel ditambahkan, juga masih perlu untuk dilatih secara profesional dan memiliki sensitifitas terhadap korban KDRT.

Selain adanya hambatan dari pihak kepolisian, ada juga hambatan dari pihak korban. Ketika pihak korban merasa kerugian yang dialaminya sangat besar, maka beberapa korban tersebut menginginkan pelaku harus dihukum atau dipenjarakan. Hal seperti itu tentu akan menyulitkan untuk menjalankan prinsip restoratif. Oleh karenanya, sudah selayaknya menjadi tugas dari pihak kepolisian dan pemerintah untuk mengedukasi masyarakat tentang banyaknya manfaat dari penerapan prinsip restoratif.

\section{Kesimpulan}

Dari seluruh uraian yang telah dijelaskan, terlihat bahwa secara normatif, kepolisian khususnya Polrestabes Semarang sudah memiliki pemahaman yang baik bagaimana menangani kasus KDRT yang memiliki sensitifitas terhadap korban. Penggunaan pendekataan keadilan restoratif dinilai tepat karena secara data agregat mampu menyelesaikan masalah KDRT secara lebih baik, tanpa juga mengabaikan penegakan hukum dengan pendekatan retributif. Ketika pihak kepolisian bisa memerankan dirinya sebagai mediator yang baik, ada harapan besar dari para korban kepolisian bisa menjadi tempat penyelasain yang baik pula terhadap kasus KDRT.

Meskipun secara normatif penanganan KDRT berjalan sudah baik, namun praktik keseharian masih memiliki beberapa persoalan yang tidak maksimal. Hal ini ditunjukkan dari fakta masih adanya korban KDRT yang menilai kurang cekatannya polisi saat menangani kasus dirinya, lebih-lebih kurang memberi perlindungan dirinya sebagai 
korban. Kenyataan seperti ini sebenarnya adalah sesuatu yang dilematis, yang tidak serta-merta bisa menyalahkan polisi. Sebab, bagaimana pun juga, jumlah kasus dan aparat kepolisian yang bertugas memang tidak sebanding. Problem sumber daya aparat, khususnya aparat perempuan yang menangani kasus KDRT, nyaris terjadi di semua unsur kepolisian hari ini.

\section{Tentang Penulis}

Anggia Putri Anggraeni adalah alumni Program Studi S1 Ilmu Pemerintahan, Departemen Politik dan Pemerintahan, Universitas Diponegoro.

Hendra Try Ardianto adalah dosen di Departemen Politik dan Pemerintahan, Universitas Diponegoro, yang memiliki area riset seputar kebijakan dan politik ekologiagraria.

\section{Ucapan Terimakasih}

Terima kasih kepada Dr. Laila Kholid Alfirdaus dan Dr. Rina Martini yang telah memberi kontribisi saran dan masukan perbaikan atas naskah awal tulisan ini.

\section{Referensi}

Aaron, T. J. (1991). Penyaringan Perkara Pidana oleh Polisi (Diskresi Kepolisian), Cetakan Pertama. Jakarta: PT. Pradnya Paramita.

Amilia, F., Mansur, M., \& Saifuddin, S. (2016). Pergeseran Nilai dan Peran Lembaga Keagamaan dalam Penanggulangan KDRT [Studi Lembaga Keagamaan di Kota Yogyakarta]. Asy-Syir'ah: Jurnal Ilmu Syari'ah dan Hukum, 50(1), 21-48.

Arief, S., \& Rahmah, A. (2018). Implementasi Mediasi Penal Dalam Penyelesaian Kasus Kekerasan Dalam Rumah Tangga (KDRT). PETITUM, 6(1 April), 8-21.

Bakar, H. A. (2017). Pemetaan Pusat Pelayanan Terpadu Pemberdayaan Perempuan dan Anak (P2TP2A) Provinsi Sumatera Barat. Kafaah: Journal of Gender Studies, 7(1), 107122.

Barata, A. A. (2003). Dasar-Dasar Pelayanan Prima (R. L. Toruan, Ed.). Jakarta: PT. Gramedia Pustaka.

Basri, S. S. K., \& Roslan, S. (2018). Kekerasan dalam Rumah Tangga (KDRT) yang Dialami Suami (Studi di Desa Kontumere Kecamatan Kabawo Kabaupaten Muna). Jurnal Neo Societal, 3(2).

Budi, T. (2016). Menyedihkan, 300 Kasus KDRT Terjadi di Kota Semarang. Sindonews.Com. Diakses dari https://daerah.sindonews.com/berita/ 1328193/22/menyedihkan-300-kasus- kdrt-terjadi-di-kota-semarang

Creswell, J. W. (2016). Research Design: Pendekatan Metode Kualitatif, Kuantitatif, dan Campuran (4th ed.). Yogyakarta: Pustaka Pelajar.

Dafeni, S. R., Mawarni, A., Nugroho, D., \& Dharmawan, Y. (2017). Hubungan beberapa faktor penyebab kekerasan dalam rumah tangga (KDRT) pada istri pus di kelurahan tinjomoyo kecamatan banyumanik tahun 2016. Jurnal kesehatan masyarakat, 5(4), 256264. 
Dwiatmodjo, H. (2011). Pelaksanaan Perlindungan Hukum Terhadap Anak Yang Menjadi Korban Tindak Pidana Di Wilayah Hukum Pengadilan Negeri Banyumas. Jurnal Dinamika Hukum, 11(2). https:/ / doi.org/10.20884/1.jdh.2011.11.2.91

Eskawati, M. Y., \& Endarto, Y. (2018). Faktor-Faktor yang Menyebabkan Terjadinya Kekerasan Dalam Rumah Tangga (KDRT) Di Kecamatan Bantul, Kabupaten Bantul, Yogyakarta. VISIKES: Jurnal Kesehatan Masyarakat, 17(01).

Glorianto, L. O. B. (2019). Peran Polisi dalam Memberikan Perlindungan Sementara Kepada Korban (Istri) dari Kekerasan Suami Dalam Rumah Tangga Berdasarkan Undang-Undang Nomor 23 Tahun 2004 Tentang Penghapusan Kekerasan Dalam Rumah Tangga (Studi Kasus Di Polrestabes Semarang). Doctoral dissertation, UNIKA Soegijapranata Semarang.

Hardiyanti, M., Purwanti, A., \& Wijaningsih, D. (2018). Optimalisasi Penanganan Korban Kekerasan Terhadap Perempuan dan Anak Melalui Lembaga Layanan Rujukan (Rumah Aman) di Kota Semarang. Diponegoro Law Journal, 7(2), 122-136.

Harkrisnowo, H. (2004). Domestic Violence (Kekerasan Dalam Rumah Tangga) Dalam Perspektif Kriminologi dan Yuridis. Indonesian Journal of International Law, 1(4), 709734. https:/ / doi.org/10.17304/ijil.vol1.4.563

Hidayati, O. (2017). Peranan Kepolisian dalam Mencegah Kekerasan dalam Rumah Tangga Di Polresta Bandar Lampung. Skripsi Fakultas Keguruan dan Ilmu Pendidikan Universitas Lampung. Diakses dari http://digilib.unila.ac.id/27415/20/ skripsi $\% 20$ tanpa $\% 20 \% 20$ bab\%20pembahasan.pdf

Ludfi, L., Jumiati, J., \& Hidayati, F. (2018). Mediasi Penal: Alternatiff Penyelesaian Perkara KDRT. Hukum Islam, 18(1), 19-39.

Lumbanbatu, H., \& Hidir, A. (2019). Peran Dalihan Na Tolu dalam Menyelesaikan Permasalahan Kekerasan dalam Rumah Tangga (Kdrt) Di Kabupaten Humbang Hasundutan. Jurnal Online Mahasiswa (JOM) Bidang Ilmu Sosial dan Ilmu Politik Vol. 6: Edisi II

Mansur, D., Arief, M., \& Gultom, E. (2007). Urgensi Perlindungan Korban Kejahatan: Antara Norma dan Realita. Jakarta: RajaGrafindo Persada.

Muljono, P. (2015). Analisis Perbandingan KDRT oleh Suami dan Istri di Jawa Barat. MIMBAR: Jurnal Sosial dan Pembangunan, 31(2), 271-282.

Pudjiarto, S. H. (1999). Hak Asasi Manusia: Kajian Filosofis dan Implementasinya dalam Hukum Pidana di Indonesia. Jakarta: Universitas Katolik Indonesia Atma Jaya.

Purba, L. (2011). Kekerasan Terhadap Perempuan: Kekerasan Dalam Rumah Tangga dan Perdagangan Orang. Diakses dari https://kemenpppa.go.id/ lib/uploads/list/7970a-5a3f9-8.-kekerasan-terhadap-perempuan.pdf

Rafikah, R. (2017). Peranan pusat pelayanan terpadu pemberdayaan perempuan dan anak (P2TP2A) dalam menghapuskan kekerasan dalam rumah tangga (KDRT) di kota Bukittinggi. Islam Realitas: Journal of Islamic E Social Studies, 1(2), 173-186.

Raharjo, S. (2009). Masalah Penegakan Hukum: Suatu Tinjauan Sosiologis. Yogyakarta: Genta Publishing. 
Rinawati, R. (2017). Pola komunikasi dalam pencegahan KDRT di Jawa barat. Mediator: Jurnal Komunikasi, 10(1), 87-96.

Simbolon, N. Y. (2020). Analisis Yuridis Terhadap Peran Polisi Dalam Penanggulangan Tindak Pidana Kdrt Di Ditreskrimsus Polda Sumut. Jurnal Ilmiah Kohesi, 4(2), 43-43.

Soetoprawiro, K., Abdurrachman, H., Idayanti, S., \& Permanasari, D. I. (2013). Pelatihan dan Pembentukan Kader KDRT dalam Penanganan dan Pendampingan Korban KDRT di Kecamatan Tarub Kabupaten Tegal. Research Report-Humanities and Social Science, 2.

Suahrdin, Y. (2007). Peranan Hukum dalam Mewujudkan Kesejahteraan Masyarakat. Jurnal Hukum Pro Jutistia, Vol. 25, pp. 270-282..

Sudarty, E., Nur, S., Nawawi, K., Arfa, N., \& Erwin, E. (2019). Penyuluhan Hukum Tentang Kekerasan Dalam Rumah Tangga (KDRT) Kepada Anggota Polisi Dan Penyidik Di Kepolisian Resort (POLRES) Kabupaten Tanjung Jabung Barat. Jurnal Karya Abdi Masyarakat, 3(2), 191-203.

Sulistyowati, I. (2006). Perempuan dan Hukum: Menuju Hukum Yang Berperspektif Kesetaraan dan Keadilan. Jakarta: Yayasan Obor Indonesia.

Tedjosaputro, L., \& Krismiyarsi, K. (2012). Kebijakan Penanggulangan Kejahatan Melalui Mediasi Penal Sebagai Alternatif Penyelesaian Tindak Pidana Kdrt. Jurnal Kriminologi Indonesia, 8(1). 